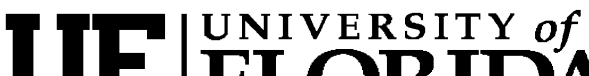 FLORIDA \\ IFAS Extension
}

\section{Gainesville's Urban Forest Structure and Composition ${ }^{1}$}

\author{
Francisco Escobedo, Jennifer A. Seitz, and Wayne Zipperer ${ }^{2}$
}

The urban forest provides a community numerous benefits. The urban forest is composed of a mix of native and non-native species introduced by people managing this forest and by residents. Because they usually contain non-native species, many urban forests often have greater species diversity than forests in the surrounding natural landscapes. This fact sheet overviews the composition and structure of the urban forest found in Gainesville, Florida.

For our purposes, the urban forest includes all trees on public and private properties within Gainesville's city limits. In the past, data collection focused on street trees and trees in public parks, but to fully understand the complexity of Gainesville's urban forest structure, data was collected by sampling 93 one-tenth-acre field plots during 2006. For the trees in these plots we measured trunk diameter at breast height (DBH), species, height, crown characteristics, location, and, when appropriate, distance and direction relative to residential buildings. The data were analyzed using USDA Forest Service's Urban Forest Effects (UFORE) model (http://www.ufore.org/). This information can provide details to urban foresters, residents, and planners to better manage this resource.
Gainesville's urban forest is composed of a diverse number of species. About 89 percent of Gainesville's trees are native to Florida. Increased tree diversity can minimize the overall impact or destruction by a species-specific insect or disease. Of the remaining 11 percent of non-native species, 2 percent are classified as Category I by the Florida Exotic Pest Plant Council (FLEPPC 2007). This classification means the exotic-invasive species alter native plant communities. An increase in the number of exotic-invasive plants can pose a risk to native plants if these out-compete and displace native plants.

The 10 most common species accounted for 66 percent of all trees. The three most common species in the city are slash pine (Pinus elliottii), laurel oak (Quercus laurifolia), and water oak (Q. nigra), at 14, 12 , and 6 percent of the total tree population, respectively (Figure 1). Tree composition varied by land use. Loblolly pine (35 percent) dominated industrial lands, laurel oaks (12 percent) dominated residential lands, water oak (40 percent) dominated transportation corridors, and common persimmon and laurel oak (25 percent) dominated commercial lands. For natural areas and vacant lands water oak and slash pine dominated. With the exception of transportation corridors, species composition formed a diverse species mixture.

1. This document is FOR 214, one of a series of the School of Forest Resources and Conservation, Florida Cooperative Extension Service, Institute of Food and Agricultural Sciences, University of Florida. Original publication date April 2009. Visit the EDIS Website at http://edis.ifas.ufl.edu.

2. Francisco Escobedo, assistant professor, Jennifer A. Seitz, Extension associate, School of Forest Resources and Conservation, Institute of Food and Agricultural Sciences, University Florida. Wayne Zipperer, research scientist, USDA Forest Service.

The Institute of Food and Agricultural Sciences (IFAS) is an Equal Opportunity Institution authorized to provide research, educational information and other services only to individuals and institutions that function with non-discrimination with respect to race, creed, color, religion, age, disability, sex, sexual orientation, marital status, national origin, political opinions or affiliations. U.S. Department of Agriculture, Cooperative Extension Service, University of Florida, IFAS, Florida A. \& M. University Cooperative Extension Program, and Boards of County Commissioners Cooperating. Millie Ferrer, Interim Dean 


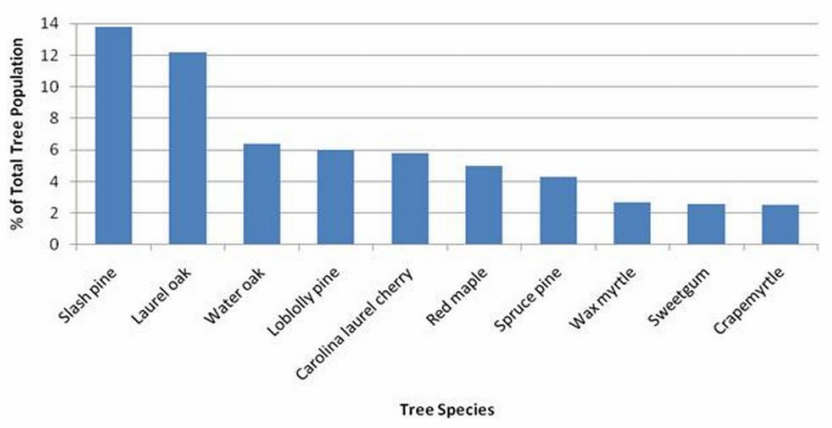

Figure 1. Top 10 most common trees in Gainesville, Florida's urban forest. Credits: Escobedo and Zipperer. 2007.

Within the city of Gainesville, the urban forest has an estimated 2,950,870 trees. The city's high proportions of large trees contribute most of the urban forest benefits (Nowak 1994, Escobedo and others 2009a, Escobedo and others 2009b, Escobedo and others 2009c). The highest density of trees occurs on vacant land or lands with no designated land use with an average of 345 trees/acre, followed by forest lands with 332 trees/acre, and then by commercial lands with 92 trees/acre (Figure 2). The average tree density in Gainesville and all its land uses is 141 trees/acre, which is greater than many other cities in the United States which usually average 14 to 119 trees/acre (Nowak and others 2006). The high average number of trees per acre in Gainesville might be due to the abundance of smaller sized trees and high regeneration rates in the understory. The distribution of tree sizes and a higher proportion of smaller trees on less managed or natural areas due to natural regeneration is typical of many urban areas in the United States (Nowak 1994).

Tree crown condition also varies by land use. Overall, 60 percent of the trees in the city were classified as good and excellent, but 21 percent were classified as being in poor condition, declining, or dead. Transportation land use had the greatest percentage of excellent and good trees, whereas commercial land use had the highest percentage of trees with poor or worst condition. Fifty-six percent of all trees sampled were between 1 and 6 inches in $\mathrm{DBH}$ and 5 percent were greater than 18 inches in $\mathrm{DBH}$.

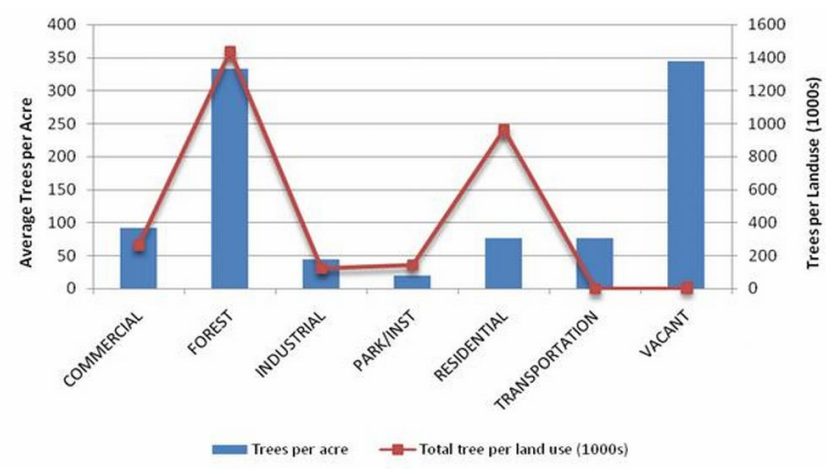

Figure 2. Tree distribution by land use of Gainesville, Florida's urban forest. Credits: Escobedo and Zipperer. 2007.

\section{Summary}

A large percentage of Gainesville's trees are smaller, indicating in most cases a younger urban forest. A high diversity of native trees can be found throughout the city. Approximately half of Gainesville's trees are found on forested lands. Trends in increased development of lands in Florida could affect urban forest structure. This information can be used to formulate management strategies to maximize benefits and minimize costs and risks to the community.

For more information about Gainesville's urban forest read the Gainesville Urban Forest Series.

\section{Literature Cited}

Escobedo, F. and W. Zipperer. 2007. Assessing Gainesville's urban forest effects and values. Unpublished raw data.

Escobedo, F., J.A. Seitz, and W. Zipperer. 2009a. Carbon sequestration and storage by Gainesville's urban forest (http://edis.ifas.ufl.edu/FR272).

Gainesville, Florida: School of Forest Resources and Conservation, Florida Cooperative Extension Service, Institute of Food and Agricultural Sciences, University of Florida.

Escobedo, F., J.A. Seitz, and W. Zipperer. 2009b. The costs of managing Gainesville's urban forest (http://edis.ifas.ufl.edu/FR279). Gainesville, Florida: School of Forest Resources and Conservation, Florida Cooperative Extension Service, Institute of Food and Agricultural Sciences, University of Florida. 
Escobedo, F., J.A. Seitz, and W. Zipperer. 2009c. Air pollution removal and temperature reduction by Gainesville's urban forest (http://edis.ifas.ufl.edu/FR278). Gainesville, Florida: School of Forest Resources and Conservation, Florida Cooperative Extension Service, Institute of Food and Agricultural Sciences, University of Florida.

FLEPPC, 2007. Florida Exotic Pest Plant Council `s 2007 List of Florida's Invasive Plant Species. Florida Exotic Pest Plant Council.

http://www.fleppc.org/list/07list_brochure.pdf (accessed January 5, 2009).

Nowak, D.J. 1994. Understanding the structure of urban forests. Journal of Forestry 92(10): 42-46.

Nowak, D.J., R.E. Hoehn, D.E. Crane, J.C. Stevens, J.T. Walton, and J. Bond. 2006. Assessing urban forest effects and values: Minneapolis' urban forest (Resource Bulletin NE-166). Newtown Square PA: United States Department of Agriculture, Forest Service, Northeastern Research Station. 